\title{
Rab GTPases as Physiological Substrates of LRRK2 Kinase
}

\author{
Wongi Seol $^{1 *}$, Daleum Nam ${ }^{1}$ and Ilhong Son ${ }^{1,2}$ \\ ${ }^{1}$ InAm Neuroscience Research Center, Sanbon Medical Center, College of Medicine, Wonkwang University, Gunpo 15865, \\ ${ }^{2}$ Department of Neurology, Sanbon Medical Center, College of Medicine, Wonkwang University, Gunpo 15865, Korea
}

\begin{abstract}
LRRK2 (Leucine-Rich Repeat Kinase 2) is a gene whose specific mutations cause Parkinson's disease (PD), the most common neurodegenerative movement disorder. LRRK2 harbors GTPase and kinase activities, two enzyme activities that play critical roles in the regulation of cellular signal transduction. Among the several LRRK2 pathogenic mutations, the most prevalent G2019S mutation increases its kinase activity when compared with the wild-type (WT), suggesting that LRRK2 kinase substrates are potential culprits of PD pathogenesis. Although there were several studies to identify LRRK2 kinase substrates, most of them mainly employed in vitro kinase assays. Therefore, it remains uncertain whether the identified substrates were real physiological substrates. However, efforts to determine physiological LRRK2 kinase substrates have recently identified several members of the Rab GTPase family as physiological LRRK2 kinase substrates. A conserved threonine or serine in the switch II domain of certain Rab GTPase family members (Rab3A/B/C/D, Rab5A/B, Rab8A/B, Rab10, Rab12, Rab29, Rab35 and Rab43) has been pinpointed to be phosphorylated by LRRK2 in cells using sophisticated phosphoproteomics technology in combination with LRRK2-specific kinase inhibitors. The Rab GTPases regulate vesicle trafficking, suggesting that LRRK2 may be a regulator of such vesicle trafficking, confirming previously suggested LRRK2 functions. However, how the consequence of the LRRK2-mediated Rab phosphorylation is related to PD pathogenesis is not clear. This review briefly summarizes the recent results about LRRK2-mediated Rab phosphorylation studies.
\end{abstract}

Key words: LRRK2, Rab GTPase, Parkinson's disease, Kinase, Vesicle trafficking

\section{INTRODUCTION}

Parkinson's disease (PD) is the second most common neurodegenerative disease, next to Alzheimer's disease and it affects 1\% 2\% of the population older than age 65 years [1]. The major symptoms of PD are related to movements such as resting tremor, rigidity, bradykinesia, postural instability and gait difficulty, although non-

Received January 4, 2019, Revised February 14, 2019,

Accepted February 21, 2019

* To whom correspondence should be addressed.

TEL: 82-31-390-2411, FAX: 82-31-390-2414

e-mail:wseolha@gmail.com movement symptoms are also observed. Two main pathological hallmarks of PD are the degeneration of dopaminergic neurons in substantia nigra pars compacta and the formation of intraneuronal inclusions called Lewy Bodies (LB) [2]. The major risk factors of PD are oxidative stress and mitochondrial dysfunction which are often caused by exposure to certain environmental factors such as pesticides [3]. In addition, old age is considered as a risk factor for PD because aging gradually increases these risk factors [4]. Because of the rapid increase of the world's aging population, the number of PD patients and the social and economical burdens associated with PD are also rapidly increasing.

The incidence of PD is mostly sporadic, although in 5\% 10\% of cases, it is genetically inherited. More than 20 PARK loci have
Copyright $\odot$ Experimental Neurobiology 2019.

www.enjournal.org
This is an Open Access article distributed under the terms of the Creative Commons Attribution Non-Commercial License (http://creativecommons.org/licenses/by-nc/4.0) which permits unrestricted non-commercial use, distribution, and reproduction in any medium, provided the original work is properly cited. 
been mapped as loci corresponding to such inherited forms of PD (i.e., familial Parkinson's disease; FPD) [5, 6]. In the mid '90s, a-synuclein (SCNA) was reported as the first PD gene to cause PD upon its mutation to A53T or A30P [7, 8] and, subsequently, duplication and triplication of SCNA were also reported in some PD families [9-11], suggesting that the $\alpha$-synuclein protein level is critical for PD pathogenesis. It is worthy to note that $\alpha$-synuclein is mainly localized in the presynaptic terminals [12] and it is a major component of LB along ubiquitin [13]. Since the report of SNCA, several other genes have been reported as PD-causative genes with either an autosomal dominant or recessive mode of inheritance. A recent GWAS (genome-wide associated study) has identified 17 novel PARK loci in addition to the $>24$ PD risk loci already known [5]. In 2004, two groups reported LRRK2/dadarin (OMIM \#607060), as an autosomal dominant PD gene corresponding to the PARK8 locus $[14,15]$ which was originally mapped on chromosome 12 through a study of a Japanese PD family [16].

\section{LRRK2 as a PD causative gene}

LRRK2 is a large protein of 2527 amino acids containing two functional enzymatic domains, the GTPase and the Ser/Thr kinase domains, and several protein-protein interaction domains such as the armadillo, ankyrin, leucine-rich repeat (LRR) and WD40 domains (Fig. 1) [17, 18]. LRRK2 is a member of the ROCO family that contains LRR, ROC (Ras of complex), COR (carboxyl terminal of ROC), and kinase domains [18, 19]. In humans, a homolog of LRRK2, LRRK1, is present as another member of the ROCO family, in addition to LRRK2 [20]. Although more than 30 DNA sequence variations of LRRK2 have been reported [21], only a few
(N1437H, R1441H/C/G, Y1699C, G2019S, I2020T) was clearly identified as pathogenic mutations with two risk factors for sporadic PD (G2385R \& R1628P) [6, 22-24]. Most of the pathogenic mutations are present in the functional domains, i.e., the ROC, COR, and Ser/Thr protein kinase (MAPKKK) domains, implying the crucial pathogenic functions of these domains for PD pathogenesis.

Among the several pathogenic LRRK2 mutations, the G2019S mutation is the most prevalent mutation and its identification [2527] has been thought to be as important as the discovery of the SNCA pathogenic mutations because of the following reasons: (1) the G2019S mutation occurs in familial as well as sporadic PD patients. Especially in specific ethnic populations such as the Northern Arabs, up to $30 \%$ of sporadic cases have been reported to contain this mutation: (2) the symptoms of patients with the G2019S mutation are similar to those of idiopathic PD cases: (3) like sporadic PD, the G2019S mutation develops late-onset PD that PD occurrence increases with age. An estimated 28\% of disease onset is at age $59,51 \%$ at 69 , and $74 \%$ at 79 years [28]: (4) Most importantly, the G2019S mutation clearly increases the kinase activity of LRRK2. These observations made a reasonable hypothesis that the increase of LRRK2 kinase activity is related to the mechanism of PD pathogenesis. Therefore, LRRK2 kinase activity could be a promising target for PD therapeutics development [29] and, so far, much effort to develop a LRRK2 kinase inhibitor as a drug to treat PD is going on in several global pharmaceutical companies [30, 31]. However, in the Asian population, the G2019S mutation was rarely observed. Instead, two risk factors, G2385R and R1628P, were observed with relatively higher frequencies [32-34]. It is also worth noting that the G2019S mutation exhibits incomplete

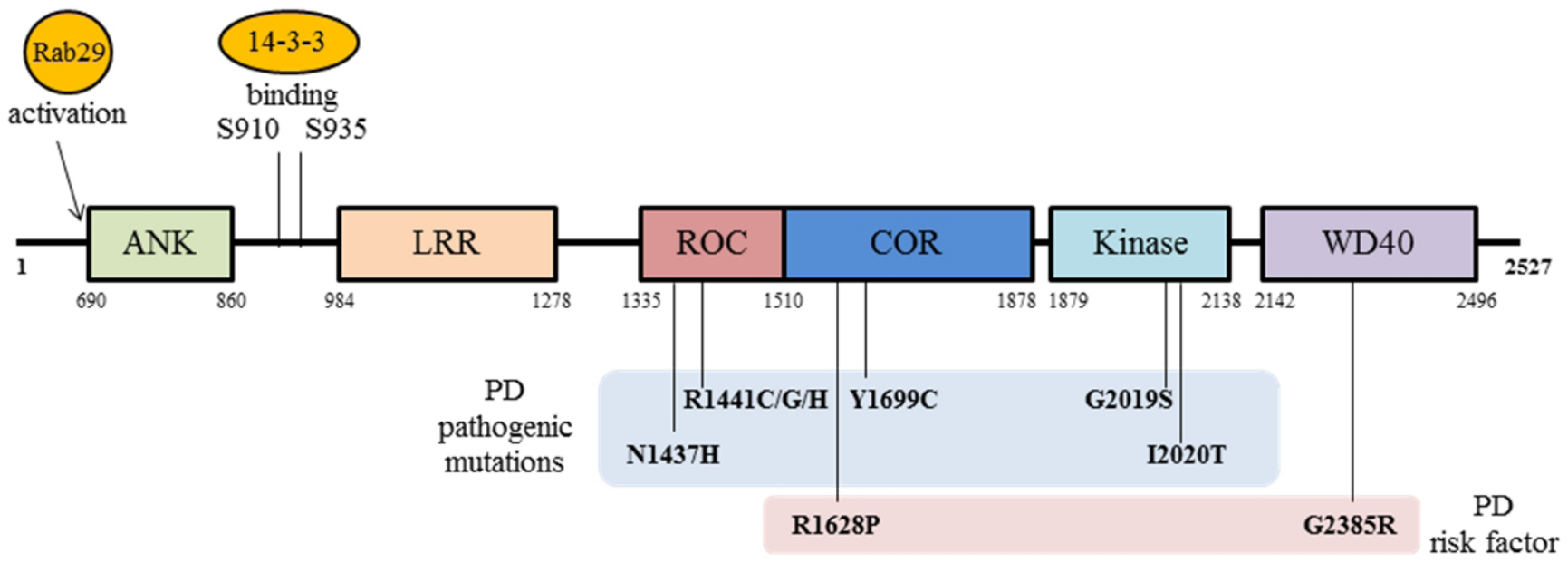

Fig. 1. A schematic view of LRRK2 with its pathogenic mutations and functional domains. ANK, ankyrin; LRR, Leucine-rich repeat; ROC, Ras of complex protein; COR, Carboxyl-terminal of ROC. Among numerous LRRK2-interacting proteins, two proteins are shown [86]. 
penetrance [28], implying that other factors such as aging and environmental elements are important in the pathogenesis of PD.

Another LRRK2 pathogenic mutation present in R1441 is the second most prevalent mutation in LRRK2 FPD cases $[6,14,15]$. Interestingly, the resulting amino acid from the R1441C mutation varies, and they include cysteine, glycine or histidine. The R1441C/ $\mathrm{G} / \mathrm{H}$ mutation is present in ROC, a GTPase domain, and, at least, the $\mathrm{R} 1441 \mathrm{C} / \mathrm{G}$ mutation has been reported to impair its GTPase activity along with another pathogenic mutation in the COR domain, the Y1699C mutation [35], again indicating the importance of LRRK2's enzymatic activities in PD pathogenicity.

More recent genetic information on LRRK2 mutations can be found in another excellent review by Monfrini et al. [6].

Because LRRK2 pathogenic mutations increase its kinase activity and cause PD, it is critical to know the in vivo phosphorylated protein targets of the LRRK2 kinase. Recently, several studies yielded promising results and this review aims to briefly summarize them. More detailed information about these studies can be found in other recent excellent reviews [23,36-38].

\section{Functions of LRRK2}

LRRK2 is a big, multi-domain protein consisting of several protein-protein interaction and functional kinase and GTPase domains playing critical roles in the regulation of signal transduction. Therefore, it is of no surprise that LRRK2 plays regulatory roles in various cellular processes, such as autophagy, synaptic vesicle trafficking, protein synthesis, dynamics of microtubule and mitochondria, etc., whose defects culminate to dopaminergic neuronal degeneration $[17,29,39-41]$. LRRK2 is ubiquitously expressed, mainly in the kidneys and lungs and it is relatively weakly expressed in the brain. LRRK2 localizes in the cytoplasm, often present in vesicles and cellular organelles [42].

Because PD is caused by defective mitochondria, an increase of oxidative stress, and impairment of protein quality control, the relationship of LRRK2 and autophagy is intensely being investigated. However, although it is obvious that LRRK2 regulates autophagy $[43,44]$, it remains unclear and controversial whether increased LRRK2 kinase activity positively or negatively regulates autophagy $[41,45]$. Although recent in vivo studies using LRRK2 knock out or G2019S transgenic animals [46, 47] suggested that LRRK2 is a negative regulator of autophagy [48], further studies are needed for clear conclusions.

LRRK2 plays critical roles in synaptic vesicle trafficking. At first, LRRK2 was reported to interact with Rab5B to impair endocytosis of synaptic vesicles [49]. Subsequently, various studies suggested LRRK2's crucial functions in synaptic vesicle trafficking. For example, LRRK2 phosphorylates endophilinA at the S75 site to affect tubulation of synaptic vesicle membrane [50] as well as endocytosis of synaptic vesicles [51]. A further study showed that EndophilinA-induced macroautophagy is activated by LRRK2mediated endophilinA phosphorylation [52]. Other studies suggested that the R1441C and the G2385R mutations differentially regulate phosphorylation of synaptic vesicle proteins and binding affinity to synaptic vesicle proteins, respectively [53-55]. In addition, LRRK2 silencing altered evoked postsynaptic currents and dynamics of synaptic vesicle recycling [56].

LRRK2's function in protein synthesis was also suggested by a study showing that the protein synthesis regulator eIF4E-BP is phosphorylated by LRRK2 and that this phosphorylation in a fly model increased protein synthesis, but also resulted in degeneration of dopaminergic neurons [57]. However, eIF4E-BP phosphorylation in the mammalian brain was not changed by LRRK2 expression [58]. Another study reported that LRRK2 pathogenic G2019S or I2020T mutation negatively controls microRNA-mediated translational repression and supported that LRRK2 mediates translation [59]. A more recent study showed regulation of protein synthesis by LRRK2-mediated phosphorylation of the ribosome protein S15 [60]. In this study, LRRK2-mediated S15 phosphorylation increased both cap-dependent and -independent protein translations [60]. However, our recent study suggested that the LRRK2 recombinant protein itself did not directly affect protein synthesis in vitro [61].

Defective mitophagy is another key mechanism in PD pathogenesis [62] and mutations in LRRK2 and other PD-causative genes such as Parkin and PINK1 resulted in mitochondrial impairment [63]. LRRK2 interacts with Dlp1/Drp1, a mitochondrial fission protein, and regulates mitochondrial dynamics, probably via LRRK2 kinase activity in neurons [64]. Recently, we have reported that LRRK2 kinase activity also facilitates mitochondria fragmentation in microglia [65]. Interestingly, one study has reported that mitochondrial DNA damage was also induced by LRRK2 kinase activity [66].

Another important function of LRRK2 is related to immunity. LRRK2 has been reported to be highly expressed in immune cells such as peripheral blood mononuclear cells $[67,68]$, suggesting its roles in immune function. LRRK2 has also been identified as a major susceptibility gene for inflammatory bowel disease (IBD $[69,70])$. With respect to this function, lysozymes in Paneth cells of LRRK2 knockout mice were degraded in the lysosome, resulting in enteric infection [71]. Recent studies reported that LRRK2 kinase activity negatively regulates phagosome maturation [72] or facilitates phagocytic activity [73]. This discrepancy definitely requires a further study for LRRK2's roles in phagocytosis. Treatment of microglia with a TLR agonist such as LPS induced activa- 
tion of LRRK2 activity and co-treatment of LPS with a specific LRRK2 kinase inhibitor attenuated neuroinflammation response $[74,75]$, suggesting a role of LRRK2 in immune functions in the brain as well.

\section{Interactions of LRRK2 with a-synuclein}

a-Synuclein protein is the main component of LB and processing of a-synuclein monomers to aggregates via oligomers and fibrils is a main pathological mechanism of PD [76]. Along with LRRK2, SNCA is also an important autosomal dominant PD-causing gene. Accordingly, the pathogenetic relationship between LRRK2 and $\alpha$-synuclein has been a topic of intense research. LRRK2 was reported to phosphorylate a-synuclein at S129 [77], but no other study confirmed this direct phosphorylation, although their colocalization in LB was reported [78]. Although results are still contradictory, the overexpression of G2019S in the brain of A53T transgenic mouse, an a-synuclein pathogenic mouse line, worsened several cellular processes related to PD, resulting in neurodegeneration [76, 79-80]. These results implied that the synergistic effect of LRRK2 and a-synuclein is cell type- or brain regiondependent because various studies reported that treatment with a LRRK2 kinase inhibitor decreases $\alpha$-synucleinopathy [76]. At the same time, these results suggested that LRRK2 could regulate processing or cellular trafficking of $a$-synuclein. In fact, two recent reports showed that LRRK2 promotes exocytosis of lysosomal contents via phosphorylation of Rab proteins which may increase lysosomal secretion of toxic $\alpha$-synuclein and $\alpha$-synuclein propagation $[81,82]$.

\section{LRRK2 kinase and its substrates}

\section{Earlier studies}

Since after LRRK2's first two reports as a PD-causative gene [14, 15], identification of endogenous substrates of LRRK2 kinase has been intensively investigated $[83,84]$. The first identified substrate was moesin, an ERM, actin binding cytoskeletal protein [85]. Subsequently, it was found that LRRK2 itself was auto-phosphorylated at $\$ 910$ and S935 sites and these phosphorylation were essential for binding of the 14-3-3 proteins [86]. An early study reported that LRRK2 also interacts with and phosphorylated tubulin-associated Tau protein, whose aggregates are often identified in the brain of PD patients [87]. Another study reported that LRRK2 facilitates Tau phosphorylation by CDK5 [88]. These and other studies [89, 90] suggested that LRRK2 could modulate microtubule stability via regulation of Tau phosphorylation. In addition, other proteins such as eIF4E-BP, snapin, p53, akt1, endophilinA, ASK1, and p62 $[50,52,57,91-95]$ have been suggested as LRRK2 kinase sub- strates, although it remains unclear whether they are physiological substrates or not.

At first, to identify LRRK2 kinase substrates, LRRK2 interacting proteins were identified after co-immunoprecipitation assays or yeast two-hybrid screenings. Then, although mostly performed under non-physiological conditions, various cellular and biochemical assays were used to confirm whether the identified proteins were substrates of the LRRK2 kinase. However, after the development of specific LRRK2 kinase inhibitors and antibodies specific for phospho-substrates, it was possible to test LRRK2mediated phosphorylation of endogenous proteins. Using this approach along with systemic proteomic analysis, several members of the Rab GTPase family were identified as endogenous substrates of the LRRK2 kinase $[96,97]$.

\section{Rab Proteins as LRRK2 kinase substrates}

Rab GTPases, a branch of the Ras superfamily, are critical regulators of intracellular vesicle trafficking [98]. It cycles an active GTPand inactive GDP-bound forms and their membrane localization also affects its functional activity [99]. In addition, Rab GTPase activity was regulated by GEF, GAP, and GDI proteins [100]. Because cargo transport along a neuron's long axon is important for the neuron's viability, impairment of Rab proteins function at various intracellular membrane trafficking points is suggested to cause neurodegeneration [98]. The human genome encodes more than 60 Rab members, some of which, such as Rab5A, 5B and 5C, are close isoforms. Defective vesicle trafficking was suggested as a culprit of PD [101] and has also been reported in cells harboring PD-causative LRRK2 or SNCA mutations [56, 102, 103]. Among proteins functioning in vesicle trafficking, impairments of Rab proteins are suggested to be linked to PD [104, 105]. In addition, a-synuclein interacts with several members of Rab proteins and overexpression of these Rab proteins rescues defective vesicle trafficking caused by pathogenic $\alpha$-synuclein $[106,107]$. Moreover, Rab29 (Rab7L1) and Rab39B have been reported as putative PDassociated genes [108, 109] in addition to VPS35 [110], another vesicle trafficking regulator (Fig. 2).

Several elegant and systemic assays using phosphoproteomics and LRRK2 kinase inhibitors revealed that members of the Rab GTPase family are cellular physiological substrates of LRRK2 kinase $[96,97,111]$. Actually, the relationship of LRRK2 to members of the Rab proteins such as Rab7, Rab5B, and Rab29, suggests that LRRK2 pathogenic mutations dysregulate vesicle trafficking [49, 112, 113]. Mann and Alessi's groups [97] developed a stringent assay by combining G2019S MEF cells treated with or without specific LRRK2 kinase inhibitors and a phosphoproteomics approach to identify physiological LRRK2 kinase substrates. This 


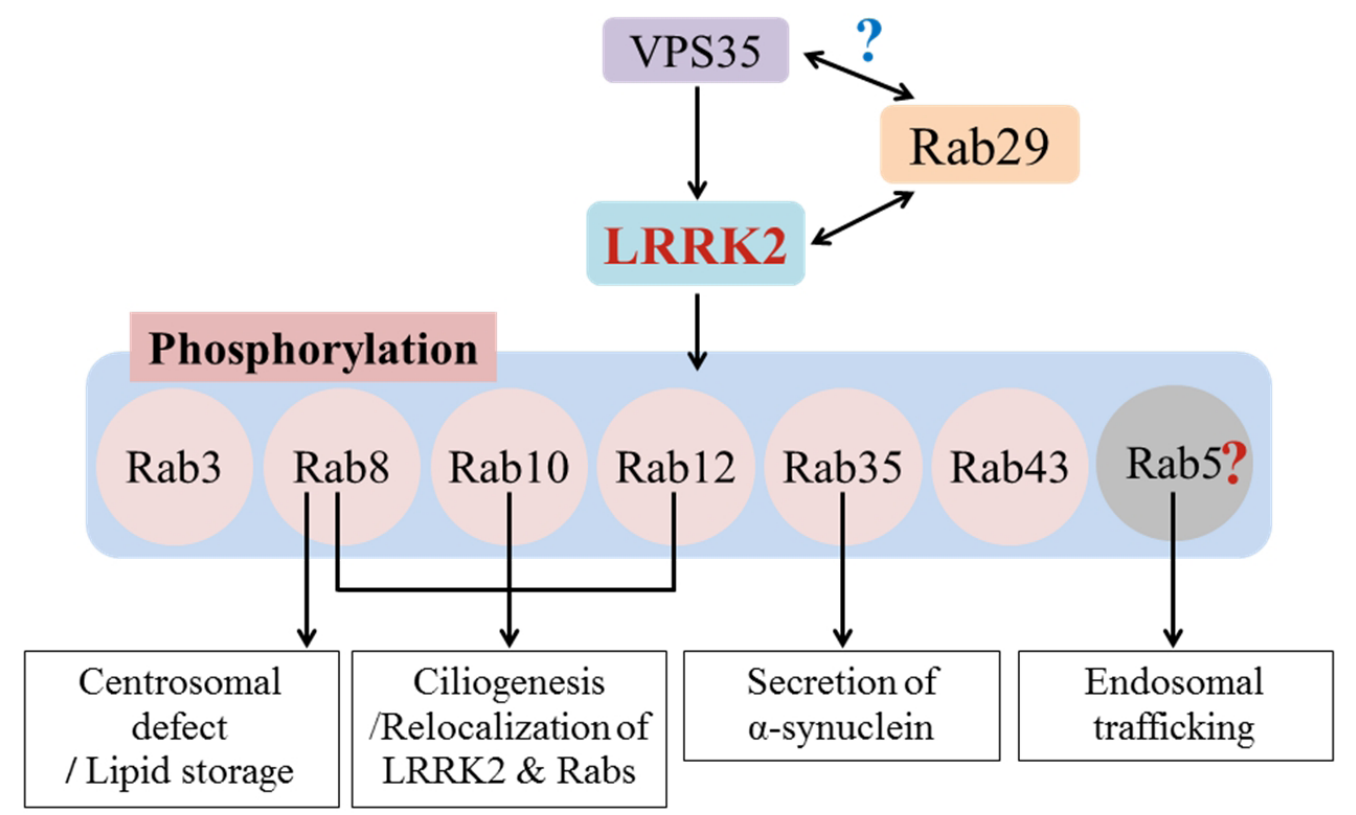

Fig. 2. A summary of consequences of LRRK2- mediated Rab phosphorylations. Two upstream regulators related to phosphorylation, VPS35 and Rab29 were shown $[81,117,120]$. Relationship between VPS35 and Rab29 is unknown yet. Among LRRK2 kinase substrates, Rab5 and Rab29 are putative substrates [96]. Activation of LRRK2 by Rab29 translocalizes LRRK2, Rab8, and Rab10 to lysosomal membranes, resulting in stabilization of Rabs on membranes after their phosphorylation [81]. elaborate study identified T73 of Rab10 and a known LRRK2 autophosphorylated site, S935, as LRRK2 kinase substrate sites. Because the T73 of Rab10 is present in the distinctive and highly conserved switch II domain of the Rab family members, they systemically tested all Rab GTPase protein members for their potential as LRRK2 kinase substrates and finally identified Rab3A/ B/C/D, Rab8A/B, Rab10, Rab12, Rab35, and Rab43 as endogenous substrates and Rab5B/C and Rab29 as potential substrates [96]. The phosphorylated sites of these Rab proteins were Thr or Ser and these sites corresponded to the T73 site of Rab10 in the switch II domain [96]. They also reported that Rab interacting lysosomal protein like (RILP) 1/2 interacts with the phosphorylated forms of certain Rabs (Rab8, 10 or 12) and this interaction regulates ciliogenesis [96]. The phosphorylation of Rab35 by LRRK2 has also been confirmed [111]. Furthermore, a recent report suggested that LRRK2-mediated Rab35 phosphorylation positively regulates $\alpha$-synuclein propagation, linking LRRK2 kinase activity to a-synuclein aggregate formation [82]. The most recent studies suggested lipid storage and centrosomal defect as functions changed after Rab8A phosphorylation by LRRK2 [114, 115]. Although various studies above have confirmed the LRRK2-meidated phosphorylation of Rab proteins, most of them were conducted in experimental settings. Therefore, whether this phosphorylation really occurs in vivo was an important question. A recent study has reported increased LRRK2 kinase activity and phosphorylated Rab10 level in dopaminergic neurons in the substantia nigra from brain tissues of patients with sporadic PD when compared with those of the control non-PD patients [116], suggesting that treat- ment with LRRK2 kinase inhibitor might be useful for not only PD patients carrying the LRRK2 mutations, but also PD patients without them.

Rab29 functions differently from other Rab proteins. Rather than just simple LRRK2 kinase substrate, Rab29 interacts with LRRK2 via the ankyrin (ANK) domain of LRRK2, localizes LRRK2 to the trans-Golgi network or the lysosome and activate LRRK2's kinase activity after its phosphorylation (Fig. 2) [81, 117-119]. Another vesicle trafficking regulator VPS35 has also been reported as a modulator of LRRK2 kinase activity. VPS35 D620N, a PD-associated pathogenic mutation, increases LRRK2-mediated phosphorylation of Rab proteins (Fig. 2) [120]. Therefore, these results have suggested that Rab29 and VPS35 function as upstream regulators of LRRK2 while Rab8/10/12/35 are LRRK2 downstream targets.

Moreover, a recent study showed that defective endolysosomal trafficking mediated by LRRK2 G2019S is partially caused by the impairment of Rab8A GTPase function [121]. As mentioned above, LRRK2 has also been reported to promote exocytosis of lysosomal contents via phosphorylation of Rab proteins which may increase lysosomal secretion of toxic $\alpha$-synuclein and $\alpha$-synuclein propagation $[81,82]$. Altogether, these studies suggested that phosphorylation of Rab proteins to dysregulate vesicle trafficking is a major function of LRRK2, thus, obviously pointing out a strong functional relationship between LRRK2 and Rab GTPases.

However, there are still unanswered questions. For example, although ciliogenesis was decreased by pathogenic LRRK2 proteins via influencing of Shh signaling [96], defective ciliogenesis has not yet been observed as a major PD-associated symptom 
Table 1. A summary of Rab proteins phosphorylated by LRRK2

\begin{tabular}{|c|c|c|}
\hline Rab proteins & Cellular phenotypes & Phenotypes of $\mathrm{KO}^{* *}$ or $\mathrm{KD}^{*}$ \\
\hline $\mathrm{Rab} 3 \mathrm{~A} / \mathrm{B} / \mathrm{C} / \mathrm{D}$ & Exocytosis & QKO; die shortly after birth, respiratory failure \\
\hline $\mathrm{Rab} 5 \mathrm{~B} / \mathrm{C}^{*}$ & Early endocytosis & KO: Loss of endosome, Failure of polarized cargo sorting \\
\hline $\mathrm{Rab8A} / \mathrm{B}$ & Endocytic recycling & $\begin{array}{l}\text { SKO; Defect of microvillus and enlarged lysosomes in gut epithelial cells } \\
\text { DKO; A ciliogenesis deficiency only under Rab10 KD }\end{array}$ \\
\hline Rab10 & $\begin{array}{l}\text { Control of ER tubule fusion and extension, } \\
\text { Endocytic recycling }\end{array}$ & KO: Embryonic lethal \\
\hline Rab12 & $\begin{array}{l}\text { Endosomal lysosome sorting and degradation, } \\
\text { Regulates autophagy }\end{array}$ & $\mathrm{KD} \mathrm{MEF}^{\dagger}$; Autophagy repression \\
\hline Rab29 (Rab7L1) & Endosomal lysosome sorting and degradation & $\begin{array}{l}\text { KO:A kidney lysosomal defect in an age-associated manner (mimic the } \\
\text { LRRK2 KO) }\end{array}$ \\
\hline Rab35 & Recycling endosomal trafficking & KO: Preweaning lethality \\
\hline Rab43 & Phosphorylated by LRRK2 & KO: Abnormal behavioral response to light \\
\hline
\end{tabular}

${ }^{\star} \mathrm{RAb} 5 \mathrm{~B} / \mathrm{C}$ has been reported as putative kinase substrates. ${ }^{\star *} \mathrm{KO}$, Knock-Out; SKO, Single Knock-Out; DKO, Double Knock-Out; QKO, Quadruple Knock-Out. ${ }^{*}$ KD: Knock Down. ${ }^{\dagger}$ MEF: Mouse Embryonic Fibroblast.

and the spectra of patients with PD and those with ciliopathies are different [36], suggesting that functions of LRRK2-mediated phosphorylated Rab proteins other than ciliogenesis are related to PD. For example, does LRRK2-mediated phosphorylation of these Rab proteins affect their GTPase activities? Does phosphorylation change the functions or the binding affinities of Rabs to their various downstream effectors? It is highly possible that LRRK2mediated phosphorylated Rab8/10/12/29/35 proteins alter their binding affinities to their various effector proteins in addition to RILP1/2 and EHBP1, thus altering the effect of functions regulated by these GTPases $[81,96,118]$. Although LRRK2-mediated Rab8 phosphorylation in SH-SY5Y cells was observed [115], most studies were performed in non-neuronal cells such as HEK 293 cells or MEF cells $[96,97]$. Therefore, the most important question is whether this phosphorylation occurs in neurons and other brain cells such as microglia and astrocytes where LRRK2 expression is higher than that of neurons. The major functional outcomes by Rabs phosphorylated by LRRK2 were summarized in Fig. 2 . The physiological functions of Rab proteins phosphorylated by LRRK2 kinase are briefly summarized in Table 1, and detailed information can be found in the excellent recent reviews [23, 36-38]. In addition to Rab proteins phosphorylated by LRRK2, other Rab proteins such as Rab1, Rab2, Rab7, Rab11A, Rab13, Rab32, Rab38 and Rab39B were also reported to be related to PD [98].

Phosphorylation of various Rab proteins by LRRK2 is now under intensive research to elucidate functional changes of phosphorylated Rabs related to PD pathogenesis. Further, such research may provide cues for PD therapeutic development.

\section{ACKNOWLEDGEMENTS}

We thank Dr. Ho, DH for his suggestion and help. We would like to apologize for not to include important results on this topic due to the space limit. Research in our laboratory is supported by the Basic Science Research Program (2018R1D1 A1B07041153) through the National Research Foundation (NRF) funded by the Ministry of Education, Science and Technology, Republic of Korea.

\section{REFERENCES}

1. Farrer MJ (2006) Genetics of Parkinson disease: paradigm shifts and future prospects. Nat Rev Genet 7:306-318.

2. Sveinbjornsdottir S (2016) The clinical symptoms of Parkinson's disease. J Neurochem 139 Suppl 1:318-324.

3. Hauser DN, Hastings TG (2013) Mitochondrial dysfunction and oxidative stress in Parkinson's disease and monogenic parkinsonism. Neurobiol Dis 51:35-42.

4. Cui H, Kong Y, Zhang H (2012) Oxidative stress, mitochondrial dysfunction, and aging. J Signal Transduct 2012:646354.

5. Chang D, Nalls MA, Hallgrímsdóttir IB, Hunkapiller J, van der Brug M, Cai F, Kerchner GA, Ayalon G, Bingol B, Sheng M, Hinds D, Behrens TW, Singleton AB, Bhangale TR, Graham RR; International Parkinson's Disease Genomics Consortium; 23andMe Research Team (2017) A meta-analysis of genomewide association studies identifies 17 new Parkinson's disease risk loci. Nat Genet 49:1511-1516.

6. Monfrini E, Di Fonzo A (2017) Leucine-rich repeat kinase (LRRK2) genetics and Parkinson's disease. Adv Neurobiol 14:3-30.

7. Polymeropoulos MH, Lavedan C, Leroy E, Ide SE, Dehejia A, Dutra A, Pike B, Root H, Rubenstein J, Boyer R, Stenroos ES, Chandrasekharappa S, Athanassiadou A, Papapetropoulos T, Johnson WG, Lazzarini AM, Duvoisin RC, Di Iorio G, Golbe LI, Nussbaum RL (1997) Mutation in the alpha-synuclein 
gene identified in families with Parkinson's disease. Science 276:2045-2047.

8. Krüger R, Kuhn W, Müller T, Woitalla D, Graeber M, Kösel S, Przuntek H, Epplen JT, Schöls L, Riess O (1998) Ala30Pro mutation in the gene encoding alpha-synuclein in Parkinson's disease. Nat Genet 18:106-108.

9. Chartier-Harlin MC, Kachergus J, Roumier C, Mouroux V, Douay X, Lincoln S, Levecque C, Larvor L, Andrieux J, Hulihan M, Waucquier N, Defebvre L, Amouyel P, Farrer M, Destée A (2004) Alpha-synuclein locus duplication as a cause of familial Parkinsons disease. Lancet 364:1167-1169.

10. Farrer M, Kachergus J, Forno L, Lincoln S, Wang DS, Hulihan M, Maraganore D, Gwinn-Hardy K, Wszolek Z, Dickson D, Langston JW (2004) Comparison of kindreds with parkinsonism and alpha-synuclein genomic multiplications. Ann Neurol 55:174-179.

11. Ibáñez P, Bonnet AM, Débarges B, Lohmann E, Tison F, Pollak P, Agid Y, Dürr A, Brice A (2004) Causal relation between alpha-synuclein gene duplication and familial Parkinson's disease. Lancet 364:1169-1171.

12. Clayton DF, George JM (1998) The synucleins: a family of proteins involved in synaptic function, plasticity, neurodegeneration and disease. Trends Neurosci 21:249-254.

13. Spillantini MG, Schmidt ML, Lee VM, Trojanowski JQ, Jakes R, Goedert M (1997) Alpha-synuclein in Lewy bodies. Nature 388:839-840.

14. Paisán-Ruíz C, Jain S, Evans EW, Gilks WP, Simón J, van der Brug M, López de Munain A, Aparicio S, Gil AM, Khan N, Johnson J, Martinez JR, Nicholl D, Carrera IM, Pena AS, de Silva R, Lees A, Martí-Massó JF, Pérez-Tur J, Wood NW, Singleton $\mathrm{AB}$ (2004) Cloning of the gene containing mutations that cause PARK8-linked Parkinson's disease. Neuron 44:595600 .

15. Zimprich A, Biskup S, Leitner P, Lichtner P, Farrer M, Lincoln S, Kachergus J, Hulihan M, Uitti RJ, Calne DB, Stoessl AJ, Pfeiffer RF, Patenge N, Carbajal IC, Vieregge P, Asmus F, MüllerMyhsok B, Dickson DW, Meitinger T, Strom TM, Wszolek ZK, Gasser T (2004) Mutations in LRRK2 cause autosomaldominant parkinsonism with pleomorphic pathology. Neuron 44:601-607.

16. Funayama M, Hasegawa K, Kowa H, Saito M, Tsuji S, Obata F (2002) A new locus for Parkinson's disease (PARK8) maps to chromosome 12p11.2-q13.1. Ann Neurol 51:296-301.

17. Price A, Manzoni C, Cookson MR, Lewis PA (2018) The LRRK2 signalling system. Cell Tissue Res 373:39-50.

18. Seol W (2010) Biochemical and molecular features of LRRK2 and its pathophysiological roles in Parkinson's disease. BMB
Rep 43:233-244.

19. Marín I, van Egmond WN, van Haastert PJ (2008) The Roco protein family: a functional perspective. FASEB J 22:31033110.

20. Korr D, Toschi L, Donner P, Pohlenz HD, Kreft B, Weiss B (2006) LRRK1 protein kinase activity is stimulated upon binding of GTP to its Roc domain. Cell Signal 18:910-920.

21. Mata IF, Kachergus JM, Taylor JP, Lincoln S, Aasly J, Lynch T, Hulihan MM, Cobb SA, Wu RM, Lu CS, Lahoz C, Wszolek ZK, Farrer MJ (2005) Lrrk2 pathogenic substitutions in Parkinson's disease. Neurogenetics 6:171-177.

22. Li JQ, Tan L, Yu JT (2014) The role of the LRRK2 gene in parkinsonism. Mol Neurodegener 9:47.

23. Araki M, Ito G, Tomita T (2018) Physiological and pathological functions of LRRK2: implications from substrate proteins. Neuronal Signal 2:NS20180005.

24. Chen ML, Wu RM (2018) LRRK 2 gene mutations in the pathophysiology of the ROCO domain and therapeutic targets for Parkinson's disease: a review. J Biomed Sci 25:52.

25. Di Fonzo A, Rohé CF, Ferreira J, Chien HF, Vacca L, Stocchi F, Guedes L, Fabrizio E, Manfredi M, Vanacore N, Goldwurm S, Breedveld G, Sampaio C, Meco G, Barbosa E, Oostra BA, Bonifati V; Italian Parkinson Genetics Network (2005) A frequent LRRK2 gene mutation associated with autosomal dominant Parkinson's disease. Lancet 365:412-415.

26. Gilks WP, Abou-Sleiman PM, Gandhi S, Jain S, Singleton A, Lees AJ, Shaw K, Bhatia KP, Bonifati V, Quinn NP, Lynch J, Healy DG, Holton JL, Revesz T, Wood NW (2005) A common LRRK2 mutation in idiopathic Parkinson's disease. Lancet 365:415-416.

27. Nichols WC, Pankratz N, Hernandez D, Paisán-Ruíz C, Jain S, Halter CA, Michaels VE, Reed T, Rudolph A, Shults CW, Singleton A, Foroud T; Parkinson Study Group-PROGENI investigators (2005) Genetic screening for a single common LRRK2 mutation in familial Parkinson's disease. Lancet 365:410-412.

28. Healy DG, Falchi M, O'Sullivan SS, Bonifati V, Durr A, Bressman S, Brice A, Aasly J, Zabetian CP, Goldwurm S, Ferreira JJ, Tolosa E, Kay DM, Klein C, Williams DR, Marras C, Lang AE, Wszolek ZK, Berciano J, Schapira AH, Lynch T, Bhatia KP, Gasser T, Lees AJ, Wood NW; International LRRK2 Consortium (2008) Phenotype, genotype, and worldwide genetic penetrance of LRRK2-associated Parkinson's disease: a casecontrol study. Lancet Neurol 7:583-590.

29. Cookson MR (2017) Mechanisms of mutant LRRK2 neurodegeneration. Adv Neurobiol 14:227-239.

30. Chan SL, Tan EK (2017) Targeting LRRK2 in Parkinson's 
disease: an update on recent developments. Expert Opin Ther Targets 21:601-610.

31. Galatsis P (2017) Leucine-rich repeat kinase 2 inhibitors: a patent review (2014-2016). Expert Opin Ther Pat 27:667676.

32. Di Fonzo A, Wu-Chou YH, Lu CS, van Doeselaar M, Simons EJ, Rohé CF, Chang HC, Chen RS, Weng YH, Vanacore N, Breedveld GJ, Oostra BA, Bonifati V (2006) A common missense variant in the LRRK2 gene, Gly2385Arg, associated with Parkinson's disease risk in Taiwan. Neurogenetics 7:133138.

33. Lu CS, Chang HC, Weng YH, Chen RS, Bonifati V, Wu-Chou YH (2008) Analysis of the LRRK2 Gly2385Arg variant in primary dystonia and multiple system atrophy in Taiwan. Parkinsonism Relat Disord 14:393-396.

34. Lu CS, Wu-Chou YH, van Doeselaar M, Simons EJ, Chang HC, Breedveld GJ, Di Fonzo A, Chen RS, Weng YH, Lai SC, Oostra BA, Bonifati V (2008) The LRRK2 Arg1628Pro variant is a risk factor for Parkinson's disease in the Chinese population. Neurogenetics 9:271-276.

35. Tsika E, Moore DJ (2013) Contribution of GTPase activity to LRRK2-associated Parkinson disease. Small GTPases 4:164170.

36. Pfeffer SR (2018) LRRK2 and Rab GTPases. Biochem Soc Trans 46:1707-1712.

37. Alessi DR, Sammler E (2018) LRRK2 kinase in Parkinson's disease. Science 360:36-37.

38. Gao Y, Wilson GR, Stephenson SE, Bozaoglu K, Farrer MJ, Lockhart PJ (2018) The emerging role of Rab GTPases in the pathogenesis of Parkinson's disease. Mov Disord 33:196-207.

39. Rideout HJ, Re DB (2017) LRRK2 and the "LRRKtosome" at the crossroads of programmed cell death: clues from RIP kinase relatives. Adv Neurobiol 14:193-208.

40. Kestenbaum M, Alcalay RN (2017) Clinical features of LRRK2 carriers with Parkinson's disease. Adv Neurobiol 14:31-48.

41. Manzoni C (2017) The LRRK2-macroautophagy axis and its relevance to Parkinson's disease. Biochem Soc Trans 45:155162.

42. Biskup S, Moore DJ, Celsi F, Higashi S, West AB, Andrabi SA, Kurkinen K, Yu SW, Savitt JM, Waldvogel HJ, Faull RL, Emson PC, Torp R, Ottersen OP, Dawson TM, Dawson VL (2006) Localization of LRRK2 to membranous and vesicular structures in mammalian brain. Ann Neurol 60:557-569.

43. Plowey ED, Cherra SJ 3rd, Liu YJ, Chu CT (2008) Role of autophagy in G2019S-LRRK2-associated neurite shortening in differentiated SH-SY5Y cells. J Neurochem 105:1048-1056.
44. Gómez-Suaga P, Hilfiker S (2012) LRRK2 as a modulator of lysosomal calcium homeostasis with downstream effects on autophagy. Autophagy 8:692-693.

45. Manzoni C, Lewis PA (2017) LRRK2 and autophagy. Adv Neurobiol 14:89-105.

46. Hinkle KM, Yue M, Behrouz B, Dächsel JC, Lincoln SJ, Bowles EE, Beevers JE, Dugger B, Winner B, Prots I, Kent CB, Nishioka K, Lin WL, Dickson DW, Janus CJ, Farrer MJ, Melrose HL (2012) LRRK2 knockout mice have an intact dopaminergic system but display alterations in exploratory and motor coordination behaviors. Mol Neurodegener 7:25.

47. Ho DH, Kim H, Nam D, Sim H, Kim J, Kim HG, Son I, Seol W (2018) LRRK2 impairs autophagy by mediating phosphorylation of leucyl-tRNA synthetase. Cell Biochem Funct 36:431-442.

48. Takagawa T, Kitani A, Fuss I, Levine B, Brant SR, Peter I, Tajima M, Nakamura S, Strober W (2018) An increase in LRRK2 suppresses autophagy and enhances Dectin-1-induced immunity in a mouse model of colitis. Sci Transl Med 10: eaan8162.

49. Shin N, Jeong H, Kwon J, Heo HY, Kwon JJ, Yun HJ, Kim CH, Han BS, Tong Y, Shen J, Hatano T, Hattori N, Kim KS, Chang S, Seol W (2008) LRRK2 regulates synaptic vesicle endocytosis. Exp Cell Res 314:2055-2065.

50. Matta S, Van Kolen K, da Cunha R, van den Bogaart G, Mandemakers W, Miskiewicz K, De Bock PJ, Morais VA, Vilain S, Haddad D, Delbroek L, Swerts J, Chávez-Gutiérrez L, Esposito G, Daneels G, Karran E, Holt M, Gevaert K, Moechars DW, De Strooper B, Verstreken P (2012) LRRK2 controls an EndoA phosphorylation cycle in synaptic endocytosis. Neuron 75:1008-1021.

51. Arranz AM, Delbroek L, Van Kolen K, Guimarães MR, Mandemakers W, Daneels G, Matta S, Calafate S, Shaban H, Baatsen P, De Bock PJ, Gevaert K, Vanden Berghe P, Verstreken P, De Strooper B, Moechars D (2015) LRRK2 functions in synaptic vesicle endocytosis through a kinase-dependent mechanism. J Cell Sci 128:541-552.

52. Soukup SF, Kuenen S, Vanhauwaert R, Manetsberger J, Hernández-Díaz S, Swerts J, Schoovaerts N, Vilain S, Gounko NV, Vints K, Geens A, De Strooper B, Verstreken P (2016) A LRRK2-dependent endophilinA phosphoswitch is critical for macroautophagy at presynaptic terminals. Neuron 92:829844.

53. Islam MS, Nolte H, Jacob W, Ziegler AB, Pütz S, Grosjean Y, Szczepanowska K, Trifunovic A, Braun T, Heumann H, Heumann R, Hovemann B, Moore DJ, Krüger M (2016) Human R1441C LRRK2 regulates the synaptic vesicle proteome and 
phosphoproteome in a Drosophila model of Parkinson's disease. Hum Mol Genet 25:5365-5382.

54. Piccoli G, Onofri F, Cirnaru MD, Kaiser CJ, Jagtap P, Kastenmüller A, Pischedda F, Marte A, von Zweydorf F, Vogt A, Giesert F, Pan L, Antonucci F, Kiel C, Zhang M, Weinkauf S, Sattler M, Sala C, Matteoli M, Ueffing M, Gloeckner CJ (2014) Leucine-rich repeat kinase 2 binds to neuronal vesicles through protein interactions mediated by its C-terminal WD40 domain. Mol Cell Biol 34:2147-2161.

55. Carrion MD, Marsicano S, Daniele F, Marte A, Pischedda F, Di Cairano E, Piovesana E, von Zweydorf F, Kremmer E, Gloeckner CJ, Onofri F, Perego C, Piccoli G (2017) The LRRK2 G2385R variant is a partial loss-of-function mutation that affects synaptic vesicle trafficking through altered protein interactions. Sci Rep 7:5377.

56. Piccoli G, Condliffe SB, Bauer M, Giesert F, Boldt K, De Astis S, Meixner A, Sarioglu H, Vogt-Weisenhorn DM, Wurst W, Gloeckner CJ, Matteoli M, Sala C, Ueffing M (2011) LRRK2 controls synaptic vesicle storage and mobilization within the recycling pool. J Neurosci 31:2225-2237.

57. Imai Y, Gehrke S, Wang HQ, Takahashi R, Hasegawa K, Oota E, Lu B (2008) Phosphorylation of 4E-BP by LRRK2 affects the maintenance of dopaminergic neurons in Drosophila. EMBO J 27:2432-2443.

58. Trancikova A, Mamais A, Webber PJ, Stafa K, Tsika E, Glauser L, West AB, Bandopadhyay R, Moore DJ (2012) Phosphorylation of 4E-BP1 in the mammalian brain is not altered by LRRK2 expression or pathogenic mutations. PLoS One 7:e47784.

59. Gehrke S, Imai Y, Sokol N, Lu B (2010) Pathogenic LRRK2 negatively regulates microRNA-mediated translational repression. Nature 466:637-641.

60. Martin I, Kim JW, Lee BD, Kang HC, Xu JC, Jia H, Stankowski J, Kim MS, Zhong J, Kumar M, Andrabi SA, Xiong Y, Dickson DW, Wszolek ZK, Pandey A, Dawson TM, Dawson VL (2014) Ribosomal protein s15 phosphorylation mediates LRRK2 neurodegeneration in Parkinson's disease. Cell 157:472-485.

61. Kim H, Son I, Seol W (2018) Effect of leucine-rich repeat kinase 2 (LRRK2) on protein synthesis. Anim Cells Syst 22:1521.

62. Larsen SB, Hanss Z, Krüger R (2018) The genetic architecture of mitochondrial dysfunction in Parkinson's disease. Cell Tissue Res 373:21-37.

63. Singh A, Zhi L, Zhang H (2019) LRRK2 and mitochondria: recent advances and current views. Brain Res 1702:96-104.

64. Wang X, Yan MH, Fujioka H, Liu J, Wilson-Delfosse A, Chen SG, Perry G, Casadesus G, Zhu X (2012) LRRK2 regulates mitochondrial dynamics and function through direct interaction with DLP1. Hum Mol Genet 21:1931-1944.

65. Ho DH, Je AR, Lee H, Son I, Kweon HS, Kim HG, Seol W (2018) LRRK2 kinase activity induces mitochondrial fission in microglia via Drp1 and modulates neuroinflammation. Exp Neurobiol 27:171-180.

66. Howlett EH, Jensen N, Belmonte F, Zafar F, Hu X, Kluss J, Schüle B, Kaufman BA, Greenamyre JT, Sanders LH (2017) LRRK2 G2019S-induced mitochondrial DNA damage is LRRK2 kinase dependent and inhibition restores mtDNA integrity in Parkinson's disease. Hum Mol Genet 26:4340-4351.

67. Thévenet J, Pescini Gobert R, Hooft van Huijsduijnen R, Wiessner C, Sagot YJ (2011) Regulation of LRRK2 expression points to a functional role in human monocyte maturation. PLoS One 6:e21519.

68. Dzamko NL (2017) LRRK2 and the immune system. Adv Neurobiol 14:123-143.

69. Anderson CA, Boucher G, Lees CW, Franke A, D’Amato M, Taylor KD, Lee JC, Goyette P, Imielinski M, Latiano A, Lagacé C, Scott R, Amininejad L, Bumpstead S, Baidoo L, Baldassano RN, Barclay M, Bayless TM, Brand S, Büning C, Colombel JF, Denson LA, De Vos M, Dubinsky M, Edwards C, Ellinghaus D, Fehrmann RS, Floyd JA, Florin T, Franchimont D, Franke L, Georges M, Glas J, Glazer NL, Guthery SL, Haritunians T, Hayward NK, Hugot JP, Jobin G, Laukens D, Lawrance I, Lémann M, Levine A, Libioulle C, Louis E, McGovern DP, Milla M, Montgomery GW, Morley KI, Mowat C, Ng A, Newman W, Ophoff RA, Papi L, Palmieri O, Peyrin-Biroulet L, Panés J, Phillips A, Prescott NJ, Proctor DD, Roberts R, Russell R, Rutgeerts P, Sanderson J, Sans M, Schumm P, Seibold F, Sharma Y, Simms LA, Seielstad M, Steinhart AH, Targan SR, van den Berg LH, Vatn M, Verspaget H, Walters T, Wijmenga C, Wilson DC, Westra HJ, Xavier RJ, Zhao ZZ, Ponsioen CY, Andersen V, Torkvist L, Gazouli M, Anagnou NP, Karlsen TH, Kupcinskas L, Sventoraityte J, Mansfield JC, Kugathasan S, Silverberg MS, Halfvarson J, Rotter JI, Mathew CG, Griffiths AM, Gearry R, Ahmad T, Brant SR, Chamaillard M, Satsangi J, Cho JH, Schreiber S, Daly MJ, Barrett JC, Parkes M, Annese V, Hakonarson H, Radford-Smith G, Duerr RH, Vermeire S, Weersma RK, Rioux JD (2011) Meta-analysis identifies 29 additional ulcerative colitis risk loci, increasing the number of confirmed associations to 47. Nat Genet 43:246-252.

70. Franke A, McGovern DP, Barrett JC, Wang K, RadfordSmith GL, Ahmad T, Lees CW, Balschun T, Lee J, Roberts R, Anderson CA, Bis JC, Bumpstead S, Ellinghaus D, Festen EM, Georges M, Green T, Haritunians T, Jostins L, Latiano A, Mathew CG, Montgomery GW, Prescott NJ, Raychaudhuri S, 
Rotter JI, Schumm P, Sharma Y, Simms LA, Taylor KD, Whiteman D, Wijmenga C, Baldassano RN, Barclay M, Bayless TM, Brand S, Büning C, Cohen A, Colombel JF, Cottone M, Stronati L, Denson T, De Vos M, D’Inca R, Dubinsky M, Edwards C, Florin T, Franchimont D, Gearry R, Glas J, Van Gossum A, Guthery SL, Halfvarson J, Verspaget HW, Hugot JP, Karban A, Laukens D, Lawrance I, Lemann M, Levine A, Libioulle C, Louis E, Mowat C, Newman W, Panés J, Phillips A, Proctor DD, Regueiro M, Russell R, Rutgeerts P, Sanderson J, Sans M, Seibold F, Steinhart AH, Stokkers PC, Torkvist L, KullakUblick G, Wilson D, Walters T, Targan SR, Brant SR, Rioux JD, D’Amato M, Weersma RK, Kugathasan S, Griffiths AM, Mansfield JC, Vermeire S, Duerr RH, Silverberg MS, Satsangi J, Schreiber S, Cho JH, Annese V, Hakonarson H, Daly MJ, Parkes M (2010) Genome-wide meta-analysis increases to 71 the number of confirmed Crohn's disease susceptibility loci. Nat Genet 42:1118-1125.

71. Zhang Q, Pan Y, Yan R, Zeng B, Wang H, Zhang X, Li W, Wei H, Liu Z (2015) Commensal bacteria direct selective cargo sorting to promote symbiosis. Nat Immunol 16:918-926.

72. Härtlova A, Herbst S, Peltier J, Rodgers A, Bilkei-Gorzo O, Fearns A, Dill BD, Lee H, Flynn R, Cowley SA, Davies P, Lewis PA, Ganley IG, Martinez J, Alessi DR, Reith AD, Trost M, Gutierrez MG (2018) LRRK2 is a negative regulator of Mycobacterium tuberculosis phagosome maturation in macrophages. EMBO J 37:e98694.

73. Kim KS, Marcogliese PC, Yang J, Callaghan SM, Resende V, Abdel-Messih E, Marras C, Visanji NP, Huang J, Schlossmacher MG, Trinkle-Mulcahy L, Slack RS, Lang AE, Park DS; Canadian Lrrk2 in Inflammation Team (CLINT) (2018) Regulation of myeloid cell phagocytosis by LRRK2 via WAVE2 complex stabilization is altered in Parkinson's disease. Proc Natl Acad Sci U S A 115:E5164-E5173.

74. Kim B, Yang MS, Choi D, Kim JH, Kim HS, Seol W, Choi S, Jou I, Kim EY, Joe EH (2012) Impaired inflammatory responses in murine Lrrk2-knockdown brain microglia. PLoS One 7:e34693.

75. Moehle MS, Webber PJ, Tse T, Sukar N, Standaert DG, DeSilva TM, Cowell RM, West AB (2012) LRRK2 inhibition attenuates microglial inflammatory responses. J Neurosci 32:16021611.

76. Daher JP (2017) Interaction of LRRK2 and a-Synuclein in Parkinson's Disease. Adv Neurobiol 14:209-226.

77. Qing H, Wong W, McGeer EG, McGeer PL (2009) Lrrk2 phosphorylates alpha synuclein at serine 129: Parkinson disease implications. Biochem Biophys Res Commun 387:149152.
78. Guerreiro PS, Huang Y, Gysbers A, Cheng D, Gai WP, Outeiro TF, Halliday GM (2013) LRRK2 interactions with a-synuclein in Parkinson's disease brains and in cell models. J Mol Med (Berl) 91:513-522.

79. Lin X, Parisiadou L, Gu XL, Wang L, Shim H, Sun L, Xie C, Long CX, Yang WJ, Ding J, Chen ZZ, Gallant PE, Tao-Cheng JH, Rudow G, Troncoso JC, Liu Z, Li Z, Cai H (2009) Leucinerich repeat kinase 2 regulates the progression of neuropathology induced by Parkinson's-disease-related mutant alphasynuclein. Neuron 64:807-827.

80. Daher JP, Pletnikova O, Biskup S, Musso A, Gellhaar S, Galter D, Troncoso JC, Lee MK, Dawson TM, Dawson VL, Moore DJ (2012) Neurodegenerative phenotypes in an A53T a-synuclein transgenic mouse model are independent of LRRK2. Hum Mol Genet 21:2420-2431.

81. Eguchi T, Kuwahara T, Sakurai M, Komori T, Fujimoto T, Ito G, Yoshimura SI, Harada A, Fukuda M, Koike M, Iwatsubo T (2018) LRRK2 and its substrate Rab GTPases are sequentially targeted onto stressed lysosomes and maintain their homeostasis. Proc Natl Acad Sci U S A 115:E9115-E9124.

82. Bae EJ, Kim DK, Kim C, Mante M, Adame A, Rockenstein E, Ulusoy A, Klinkenberg M, Jeong GR, Bae JR, Lee C, Lee HJ, Lee BD, Di Monte DA, Masliah E, Lee SJ (2018) LRRK2 kinase regulates $\alpha$-synuclein propagation via RAB35 phosphorylation. Nat Commun 9:3465.

83. Nichols RJ (2017) LRRK2 phosphorylation. Adv Neurobiol 14:51-70.

84. Porras P, Duesbury M, Fabregat A, Ueffing M, Orchard S, Gloeckner CJ, Hermjakob H (2015) A visual review of the interactome of LRRK2: using deep-curated molecular interaction data to represent biology. Proteomics 15:1390-1404.

85. Parisiadou L, Xie C, Cho HJ, Lin X, Gu XL, Long CX, Lobbestael E, Baekelandt V, Taymans JM, Sun L, Cai H (2009) Phosphorylation of ezrin/radixin/moesin proteins by LRRK2 promotes the rearrangement of actin cytoskeleton in neuronal morphogenesis. J Neurosci 29:13971-13980.

86. Li X, Wang QJ, Pan N, Lee S, Zhao Y, Chait BT, Yue Z (2011) Phosphorylation-dependent 14-3-3 binding to LRRK2 is impaired by common mutations of familial Parkinson's disease. PLoS One 6:e17153.

87. Kawakami F, Yabata T, Ohta E, Maekawa T, Shimada N, Suzuki M, Maruyama H, Ichikawa T, Obata F (2012) LRRK2 phosphorylates tubulin-associated tau but not the free molecule: LRRK2-mediated regulation of the tau-tubulin association and neurite outgrowth. PLoS One 7:e30834.

88. Shanley MR, Hawley D, Leung S, Zaidi NF, Dave R, Schlosser KA, Bandopadhyay R, Gerber SA, Liu M (2015) LRRK2 fa- 
cilitates tau phosphorylation through strong interaction with tau and cdk5. Biochemistry 54:5198-5208.

89. Guerreiro PS, Gerhardt E, Lopes da Fonseca T, Bähr M, Outeiro TF, Eckermann K (2016) LRRK2 promotes tau accumulation, aggregation and release. Mol Neurobiol 53:3124-3135.

90. Nguyen AP, Daniel G, Valdés P, Islam MS, Schneider BL, Moore DJ (2018) G2019S LRRK2 enhances the neuronal transmission of tau in the mouse brain. Hum Mol Genet 27:120-134.

91. Yun HJ, Park J, Ho DH, Kim H, Kim CH, Oh H, Ga I, Seo H, Chang S, Son I, Seol W (2013) LRRK2 phosphorylates Snapin and inhibits interaction of Snapin with SNAP-25. Exp Mol Med 45:e36.

92. Ho DH, Seol W, Eun JH, Son IH (2017) Phosphorylation of p53 by LRRK2 induces microglial tumor necrosis factor a-mediated neurotoxicity. Biochem Biophys Res Commun 482:1088-1094.

93. Ohta E, Kawakami F, Kubo M, Obata F (2011) LRRK2 directly phosphorylates Akt1 as a possible physiological substrate: impairment of the kinase activity by Parkinson's diseaseassociated mutations. FEBS Lett 585:2165-2170.

94. Yoon JH, Mo JS, Kim MY, Ann EJ, Ahn JS, Jo EH, Lee HJ, Lee YC, Seol W, Yarmoluk SM, Gasser T, Kahle PJ, Liu GH, Belmonte JC, Park HS (2017) LRRK2 functions as a scaffolding kinase of ASK1-mediated neuronal cell death. Biochim Biophys Acta Mol Cell Res 1864:2356-2368.

95. Kalogeropulou AF, Zhao J, Bolliger MF, Memou A, Narasimha S, Molitor TP, Wilson WH, Rideout HJ, Nichols RJ (2018) P62/SQSTM1 is a novel leucine-rich repeat kinase 2 (LRRK2) substrate that enhances neuronal toxicity. Biochem J 475:1271-1293.

96. Steger M, Diez F, Dhekne HS, Lis P, Nirujogi RS, Karayel O, Tonelli F, Martinez TN, Lorentzen E, Pfeffer SR, Alessi DR, Mann M (2017) Systematic proteomic analysis of LRRK2mediated Rab GTPase phosphorylation establishes a connection to ciliogenesis. eLife 6:e31012.

97. Steger M, Tonelli F, Ito G, Davies P, Trost M, Vetter M, Wachter S, Lorentzen E, Duddy G, Wilson S, Baptista MA, Fiske BK, Fell MJ, Morrow JA, Reith AD, Alessi DR, Mann M (2016) Phosphoproteomics reveals that Parkinson's disease kinase LRRK2 regulates a subset of Rab GTPases. eLife 5:e12813.

98. Kiral FR, Kohrs FE, Jin EJ, Hiesinger PR (2018) Rab GTPases and membrane trafficking in neurodegeneration. Curr Biol 28:R471-R486.

99. Zhen Y, Stenmark H (2015) Cellular functions of Rab GTPases at a glance. J Cell Sci 128:3171-3176.

100. Stenmark H (2009) Rab GTPases as coordinators of vesicle traffic. Nat Rev Mol Cell Biol 10:513-525.

101. Esposito G, Ana Clara F, Verstreken P (2012) Synaptic vesicle trafficking and Parkinson's disease. Dev Neurobiol 72:134144.

102. Cirnaru MD, Marte A, Belluzzi E, Russo I, Gabrielli M, Longo F, Arcuri L, Murru L, Bubacco L, Matteoli M, Fedele E, Sala C, Passafaro M, Morari M, Greggio E, Onofri F, Piccoli G (2014) LRRK2 kinase activity regulates synaptic vesicle trafficking and neurotransmitter release through modulation of LRRK2 macro-molecular complex. Front Mol Neurosci 7:49.

103. Scott D, Roy S (2012) a-Synuclein inhibits intersynaptic vesicle mobility and maintains recycling-pool homeostasis. J Neurosci 32:10129-10135.

104. Tang BL (2017) Rabs, membrane dynamics, and Parkinson's disease. J Cell Physiol 232:1626-1633.

105. Rivero-Ríos P, Gómez-Suaga P, Fernández B, Madero-Pérez J, Schwab AJ, Ebert AD, Hilfiker S (2015) Alterations in late endocytic trafficking related to the pathobiology of LRRK2linked Parkinson's disease. Biochem Soc Trans 43:390-395.

106. Cooper AA, Gitler AD, Cashikar A, Haynes CM, Hill KJ, Bhullar B, Liu K, Xu K, Strathearn KE, Liu F, Cao S, Caldwell KA, Caldwell GA, Marsischky G, Kolodner RD, Labaer J, Rochet JC, Bonini NM, Lindquist S (2006) Alpha-synuclein blocks ER-Golgi traffic and Rab1 rescues neuron loss in Parkinson's models. Science 313:324-328.

107. Shi MM, Shi CH, Xu YM (2017) Rab GTPases: the key players in the molecular pathway of Parkinson's disease. Front Cell Neurosci 11:81.

108. Khaligh A, Goudarzian M, Moslem A, Mehrtash A, Jamshidi J, Darvish H, Emamalizadeh B (2017) RAB7L1 promoter polymorphism and risk of Parkinson's disease; a case-control study. Neurol Res 39:468-471.

109. Wilson GR, Sim JC, McLean C, Giannandrea M, Galea CA, Riseley JR, Stephenson SE, Fitzpatrick E, Haas SA, Pope K, Hogan KJ, Gregg RG, Bromhead CJ, Wargowski DS, Lawrence CH, James PA, Churchyard A, Gao Y, Phelan DG, Gillies G, Salce N, Stanford L, Marsh AP, Mignogna ML, Hayflick SJ, Leventer RJ, Delatycki MB, Mellick GD, Kalscheuer VM, D’Adamo P, Bahlo M, Amor DJ, Lockhart PJ (2014) Mutations in RAB39B cause X-linked intellectual disability and early-onset Parkinson disease with a-synuclein pathology. Am J Hum Genet 95:729-735.

110. Zimprich A, Benet-Pagès A, Struhal W, Graf E, Eck SH, Offman MN, Haubenberger D, Spielberger S, Schulte EC, Lichtner P, Rossle SC, Klopp N, Wolf E, Seppi K, Pirker W, Presslauer S, Mollenhauer B, Katzenschlager R, Foki T, Hotzy C, Reinthaler E, Harutyunyan A, Kralovics R, Peters A, Zim- 
prich F, Brücke T, Poewe W, Auff E, Trenkwalder C, Rost B, Ransmayr G, Winkelmann J, Meitinger T, Strom TM (2011) A mutation in VPS35, encoding a subunit of the retromer complex, causes late-onset Parkinson disease. Am J Hum Genet 89:168-175.

111. Jeong GR, Jang EH, Bae JR, Jun S, Kang HC, Park CH, Shin JH, Yamamoto Y, Tanaka-Yamamoto K, Dawson VL, Dawson TM, Hur EM, Lee BD (2018) Dysregulated phosphorylation of Rab GTPases by LRRK2 induces neurodegeneration. Mol Neurodegener 13:8.

112. Dodson MW, Zhang T, Jiang C, Chen S, Guo M (2012) Roles of the Drosophila LRRK2 homolog in Rab7-dependent lysosomal positioning. Hum Mol Genet 21:1350-1363.

113. MacLeod DA, Rhinn H, Kuwahara T, Zolin A, Di Paolo G, McCabe BD, Marder KS, Honig LS, Clark LN, Small SA, Abeliovich A (2013) RAB7L1 interacts with LRRK2 to modify intraneuronal protein sorting and Parkinson's disease risk. Neuron 77:425-439.

114. Yu M, Arshad M, Wang W, Zhao D, Xu L, Zhou L (2018) LRRK2 mediated Rab8a phosphorylation promotes lipid storage. Lipids Health Dis 17:34.

115. Madero-Pérez J, Fdez E, Fernández B, Lara Ordóñez AJ, Blanca Ramírez M, Gómez-Suaga P, Waschbüsch D, Lobbestael E, Baekelandt V, Nairn AC, Ruiz-Martínez J, Aiastui A, López de Munain A, Lis P, Comptdaer T, Taymans JM, Chartier-Harlin MC, Beilina A, Gonnelli A, Cookson MR, Greggio E, Hilfiker $S$ (2018) Parkinson disease-associated mutations in LRRK2 cause centrosomal defects via Rab8a phosphorylation. Mol Neurodegener 13:3.

116. Di Maio R, Hoffman EK, Rocha EM, Keeney MT, Sanders LH,
De Miranda BR, Zharikov A, Van Laar A, Stepan AF, Lanz TA, Kofler JK, Burton EA, Alessi DR, Hastings TG, Greenamyre JT (2018) LRRK2 activation in idiopathic Parkinson's disease. Sci Transl Med 10:eaar5429.

117. Purlyte E, Dhekne HS, Sarhan AR, Gomez R, Lis P, Wightman M, Martinez TN, Tonelli F, Pfeffer SR, Alessi DR (2018) Rab29 activation of the Parkinson's disease-associated LRRK2 kinase. EMBO J 37:1-18.

118. Liu Z, Bryant N, Kumaran R, Beilina A, Abeliovich A, Cookson MR, West AB (2018) LRRK2 phosphorylates membranebound Rabs and is activated by GTP-bound Rab7L1 to promote recruitment to the trans-Golgi network. Hum Mol Genet 27:385-395.

119. Fujimoto T, Kuwahara T, Eguchi T, Sakurai M, Komori T, Iwatsubo T (2018) Parkinson's disease-associated mutant LRRK2 phosphorylates Rab7L1 and modifies trans-Golgi morphology. Biochem Biophys Res Commun 495:17081715 .

120. Mir R, Tonelli F, Lis P, Macartney T, Polinski NK, Martinez TN, Chou MY, Howden AJ, König T, Hotzy C, Milenkovic I, Brücke T, Zimprich A, Sammler E, Alessi DR (2018) The Parkinson's disease VPS35[D620N] mutation enhances LRRK2mediated Rab protein phosphorylation in mouse and human. Biochem J 475:1861-1883.

121. Rivero-Ríos P, Romo-Lozano M, Madero-Pérez J, Thomas AP, Biosa A, Greggio E, Hilfiker S (2019) The G2019S variant of leucine-rich repeat kinase 2 (LRRK2) alters endolysosomal trafficking by impairing the function of the GTPase RAB8A. J Biol Chem (in press). 